\title{
Hemoglobin Subunit Theta-1
}

National Cancer Institute

\section{Source}

National Cancer Institute. Hemoglobin Subunit Theta-1. NCI Thesaurus. Code C84974.

Hemog lobin subunit theta-1 (142 aa, $\sim 16 \mathrm{kDa}$ ) is encoded by the human HBQ1 gene.

This protein may play a role in the transport of oxygen to embryonic tissues. 